\title{
An outside-inside view of exclusive practice within an inclusive mainstream school.
}

\begin{abstract}
This article is a reflection on a sabbatical experience in a mainstream school where an inclusive ethos underpinned the curriculum and environmental approaches for all children. The period as Acting Head teacher raised some challenges for me in reconciling inclusion for all children and the exclusive nature of some professional and physical spaces available to the community of adults working in the school. It has highlighted some development opportunities for the senior management of the school and its governing body.
\end{abstract}

Key words: leadership, critical friendship, initiatives, space, exclusion.

An opportunity arose to revisit day-to-day life as a practitioner in an infant and nursery school, to explore leadership through Assistant Headship and lead and manage alongside colleagues rather than in a large Higher Education Institution. A professional aim was to support the senior management team of the school in the curriculum and environmental initiatives set in place some years ago in a research/in-service partnership and then sustained by the arrival of many newly qualified teachers from that Higher Education Institution.

This brief, retrospective account reflects the subjectivity of a participant observer in one school, a critical judgement of unresolved leadership challenges that might be more or less representative of other schools and offers an opportunity to reflect upon leadership and management approaches seen at close hand. The importance of critical friendship and continued open discussion with the Head teacher [HT] is on-going through being invited to become Chair of Governors.

I looked forward to developing management and leadership skills in what can be described as a very inclusive school, one where

"inclusion concerns everybody- all learners, and all members of the school." (Armstrong and Barton, 2007: p.1)

From regular visits and staff development sessions, I recognised that the school fully concerned itself with the well-being of children and their families through the relationships and initiatives developed alongside and with a relatively young and enthusiastic group of teachers, an active local community, loyal families and a skilful team of TAs. All children's interests form the basis of the curriculum offer with a degree of choice, autonomy and responsibility towards the independent use of resources and freedom to work and play in the outdoor environment for all children, rarely seen in many schools. At no time are any children excluded from the routines, spaces, activities, whole group and small group times. Makaton is used as a dual communication for all children who often use signs and symbols in conversation with each other.

My frequent visits over the years, welcomed as a source of ideas, resources, in-service training, current research (and trainee teachers) had given me a sense of anticipated 
inclusion within a very familiar school staff team. Armstrong and Barton (2007) suggest inclusion is

"fundamentally about issues of human rights, equity, social justice and the ` struggle for a non-discriminatory society."(p.10)

What I observed was an exclusive use of adult social and physical spaces inhabited by a dominant group of teachers and, furthermore, in the leadership styles of the senior management team I had been invited to join, did not seem to represent

"the heart of inclusive policy and practice."(Ibid)

in the relationships with the adult school community.

The following concerns, questions and journal entries may offer a critical lens through which to view inclusive environments for staff. The journal was sustained throughout the sabbatical as a record of professional reflection, for MacNaughton (2005) reminds that

"identifying the stories (of individuals or societies) is a political act”. (p.4).

Prosser(1999) in Bush and Middlewood, (2005) refers to the 'dark underworld' of school culture and links it to the concept of micro politics:

"The micro political perspective recognized that formal powers, rules, regulations, traditions and rituals were capable of being subverted by individuals, groups, or affiliations in schools'.( p.57)

It would be sinister indeed to refer to the staffroom environment as a 'dark underworld' and yet, on a daily basis I watched the staffroom space as a place of exclusion, one which had very defined spaces for individuals and groups who, in addition to defining 'their' space with a daily gathering, also 'created' a barrier with teacher folders, resources, boxes and handbags. The group occupying this space were young teachers (not the two NQTs) and the Deputy Head. Teaching assistants were not welcomed into this group, or were ignored if the space was 'invaded by outsiders'. Staff, not included or welcomed into what was a very defined space, often commented upon this exclusive group and their behaviour seemed to be more widespread in the way the school was managed and led.

[HT appears to avoid conflict with the group, spends little time in staffroom, actually more removed from staff than I would have thought; 11/10/07. HT does not communicate with staff about what he is planning. I am not sure he talks enough to staff as he only occasionally goes into classrooms, 9/5/08].

Western (2008) suggests that

"the individual leader is socially constructed by those 'followers' around them"; (p16)

but there is an interdependent relationship here with Earley and Weindling's (2004) notion that

"The importance of heads as 'lead learners' and creators of learning communities cannot be underestimated .Modern notions of leadership, including distributed leadership, rely heavily on leadership, alongside effective management, being successfully demonstrated at the apex of the institution." (pp.169-170)

The school, in the past eight years under the current Head teacher, has become a radically different learning context from a majority of mainstream schools in the way that all children are encouraged to follow their own interests, and a year has not gone by 
where the physical environment has not altered or classrooms have not become key stage units, or staff have not been encouraged to lead on pedagogical changes; and yet I

"reflect that staff and school development have not progressed holistically; induction is non-existent, although expectations of performance high and staff over-confident of innovation that appears not to need staff review, 26/10/07. Head teacher concurs that many activities are top-down and staff reluctant to look at bigger picture, or be critically reflective, 17/7/08. Appraisals would help. Staff appear not to have been given explicit instructions/model to follow, 10/3/08".

In addition,

"The literature on collegiality (e.g. Bush 2003) shows that leaders are more likely to cede power to others when they are confident that their own educational values will not be compromised by doing so."(Bush and Middlewood, 2005; p.55)

It was interesting to note that having been given responsibility for encouraging staff development, an experienced member of staff

"talked to me about visiting good practice in mathematics in schools and I had helpful responses from a colleague at university about where to visit. The Head teacher says that it is pointless going anywhere else to look at what they are doing, 29/2/08".

I also recorded that in the year's sabbatical, there was only one senior management meeting between myself as Assistant Head teacher, the Deputy Head and Head teacher.

What I perceived were a set of barriers to effective leadership and management, some erected through senior management disunity, some through initiative overload where a school was radically aiming at an alternative, child-centred curriculum and use of environment but exacerbated through a lack of genuine and general dialogue. Perhaps through the underdevelopment of newly qualified staff, some barriers were self-imposed as their protection against self-perceived risk;

"I discussed with the Head teacher his delegated management style as a critical friend, and how that might make staff uneasy with carrying out so many initiatives when it appeared that they were unready, unwilling or unable to take responsibility. Does distributed leadership have a mutual dependency on trust? If staff do not trust, they will not allow themselves to be accountable for either their actions or level of inactivity; it is a risk for them, 10/3/08".

What the barriers seemed to bring into effect was a staff environment that was failing to include all staff. As an experienced academic team leader in Higher Education, what I aimed to do through sensitive discussion with the HT was to raise these challenges to secure the long term success of the school, and confront those issues of self-esteem that appear to be hampering the overall philosophical aims of the school. One of the questions that troubled me throughout was

'How can a group of staff who rehearse the rhetoric of inclusivity for children, be so exclusive in their relations with staff colleagues?'

If we accept Dahlberg et al's (1999) contention that schools are ideological and political terrains, with dominant and subordinate voices framing local political conditions then the nature of the voices experienced within the school presented quite a challenge to the 
notion, power and practice of inclusivity. What I had observed was the exercise of power over 'subordinate' staff voices, from the Headteacher and Deputy Headteacher, but cascading (down) to the relationships between young teaching staff and the TAs, and to a certain extent any newly arrived staff within the school. I further reflected on any evidence of dominant and subordinate relationships between staff and children in the school and how the constant interplay of new initiatives, staffing structures and reorganisation of the environment into learning units for different children was perhaps exerting power over the children, their families and community. Constant change is destabilizing for children and staff, particularly those who have a deeper sense of vulnerability or lack of resilience and autonomy. Accompanied by a lack of clear explanation and rationale through under developed leadership and management skills challenged my perception of this inclusive school.

With the established staff and senior management group frequently rehearsing that the 'knowledge' within the school was 'the only right' way to organize curriculum and learning environment for all children between the ages of 3-7, I would argue that this "decisive influence of practice made a regime of truth in everyday experiences constitute boundaries that are powerful". (Foucault, 1980a in MacNaughton, 2005. P19)

Post-sabbatical, I continue to work with the school, encouraging the voices within the governors community to ask questions, interrogate working practice and encourage a more ecological relationship with the staff at the school. There have been a number of issues and concerns around the HT's relationship with parents and the local authority and his insistence that his approach is the only approach appropriate for their children's welfare. These I have challenged having created a (limited) repertoire for critical challenge.

Returning to the Higher Education Institution and a new academic team to lead and manage has resulted in a more honest distributive style of management where individuals within the team have been trusted to challenge, act, be accountable for, work in partnership, pursue individual lines of enquiry, join in and participate and adopt leadership of ideas, research and ways of working. New members of staff have been more assiduously inducted and mentored and appraisals have become more effective 
and meaningful for staff in that promotions and role responsibilities have been undertaken with enthusiasm. The output of research, books and conference papers has escalated and a new academic plan for the team has been co-constructed with more than the anticipated engagement, thus empowering the majority of the team and ensuring it's longer term well-being and success. The team has been given space and authority to grow rather than be inhibited and exclusive in their relationships with others, a consequence of experiencing a less than inclusive leadership style that was struggling to succeed in a local school.

\section{References}

Bush, T. \& Middlewood, D. (2005) Leading and Managing People in Education London: Sage Publications

Dahlberg, G. \& Moss, P.(1999) Beyond Quality in Early Childhood care and Education London: Routledge Falmer

Earley, P. \& Weindling, D. (2004) Understanding School Leadership London: PCP

MacNaughton, G. (2005) Doing Foucault in Early Childhood Studies. Applying

Poststructural Ideas Abingdon: Routledge

Prosser, J. (1999) Chapter 4 in T.Bush \& D. Middlewood (2005)

Richards, G. \& Armstrong, F. Eds (2007) Key issues for Teaching Assistants. Working in diverse and inclusive classrooms. London: Taylor and Francis Routledge

Western, S. (2008) Leadership A Critical Text London: Sage Publications

annie.woods@ntu.ac.uk

This article is not currently being considered for publication elsewhere. 


\section{Annie Woods \\ School of Education \\ Nottingham Trent University}

